\title{
Measuring the concentration of some hormones in patients sera of polycystic ovaries
}

\author{
Bushra. F. Hassan* \\ Received 10, May, 2009 \\ Accepted 23, December, 2009
}

\begin{abstract}
:
Extensive evaluation of 76 women with polycystic ovary syndrome compared with 25 fertile women as control group was achieved by routine investigations and hormonal study of each female which were done in one period during the menstrual cycle. Then the women with $\mathrm{PCO}_{\mathrm{s}}$ have been divided into 2 groups according to their menstrual cycle (irregular menstrual cycle) during assessing their hormonal profiles as follow:-

1- (54) Patients with oligomenorrhea.

2- (22) Patients with menorrhea.

This study shows that the women with PCOs have different clinical features taken from a history of disease of all of the women.

Those features were distributed as follow: $57.92 \%$ of them suffer from hirsutism. $19.24 \%$ suffer from irregular menstrual cycle, obesity in $67 \%, 9$ patient with acne vulgaris, and more than $50 \%$ of them have most of the clinical symptoms at same time. It is also found that the hormonal disorder is the main cause of this disease with other cawes.
\end{abstract}

\section{Key words: LH, FSH hormones, poly cystic ovaries}

\section{Introduction:}

Polycystie ovary syndrome (PCOs) is a common condition characterized by menstrual abnormalities and clinical or biochemical future of hyperrandrogensim [1,2]. And it can be defined as a hormonal imbalance that can cause irregular periods and acne on ovulation in reproductive age $[3,4]$. The name of (PCOs) is given because one of the most common results of these diseases is the formation of many cysts on the ovaries, but the problems it produces are manifold [3]. Although (PCOs) is known to be associated with reproductive morbidity and increased risk for endometrial Cancer, so (PCOs) is one of the most common endocrine disorders [5]. Although its etiology remains unknown but it is involved with aberration of substance that lead to follicular growth [6]. (PCOs) is associated also with an ovulatory infertility and metabolic disturbances [7]. The classical symptoms of (PCOs) include infertility, amenorrhea of signs of hirsutism and obesity as originally described by stein and Leven that in 1935. However, the clinical significance of polycystic ovary in asymptomatic women is still under investigation[8-10]. Many complications arise from this disorder which include: hormonal imbalance, infertility, adult acne, a hump on the upper back, patches of the dark skin under the arms, male-pattern baldness, adrenal hyperplasia, high blood pressure and obesity[11]. Ovaries are slightly enlarged and contain 6 or more cysts located at which have leed to the descriptive term, the size of these cysts general can be usually be detected by ultrasound examination [12].

*Chemistry Department/ College of Science for Women 


\section{Materials and Methods:}

This study was carried out on seventy six patients with (PCOs) with age ranged between (16-40) years during the period of nearly one year, which obtained from Kamal Al-Samaraay hospital /Baghdad, and Al-Kadhimya teaching hospital/Baghdad, also twenty- five normal regularmenstruating women with proved fertility, whose age ranged between (15-45) years, act as the control group.

Table (1) summarized the variable of subjects under study.

\begin{tabular}{|c|c|c|c|}
\hline groups & $\begin{array}{c}\text { Number of } \\
\text { patient }\end{array}$ & $\begin{array}{c}\text { Age Range } \\
\text { ( year) }\end{array}$ & $\begin{array}{c}\text { Mean } \\
\text { (year) }\end{array}$ \\
\hline Controls & 25 & $15-45$ & 30 \\
\hline Patients & 76 & $10-40$ & 28 \\
\hline
\end{tabular}

The patients were presented with menstrual irregularities (menstrual cycle length was between 50 day and 6 months), (mean \pm SD) days.

Centrifugation of the fasting blood sample was done at $3000 \mathrm{rpm}$ to separate serum samples. Then transferred into plastic cuvettes, which was used of measuring hormones, the tubes were stored at $-20^{\circ} \mathrm{C}$ until analysis.

\section{Hormonal assay kit:}

FSH, LH and Testosterone were estimated by mini VIDAS using a biomerieux kits Sa. 69230 marcy I'Etoile- France (No. 06268I, 06267 K and $09345 \mathrm{~B}$ respectively.

At the end of the assay, results are automatically calculated by mini VIDAS in relation to the calibration curve stored in memory, and then printed out. All the previous steps were also applied LH and testosterone hormones in order to measure the concentration in all PCOs samples unit.

\section{Results:}

The level of LH and FSH in sera of PCOS and control groups were indicated in table (2). There was an increase level of LH in PCOs group compared with that found in control group, this difference is statically significant $(\mathrm{p}<0.05)$, also there was a significant differences between control and PCOs group for FSH level (P> 0.05), LH/FSH ratio was significally higher than normal control ((P> 0.05) (table 2). Also testosterone levels in PCOs was more than that found in the control group (Table 2).

1- Luteinzing hormone (LH):-

Serum LH levels obtained was elevated in $(79.25 \%)$ of $\mathrm{PCO}_{\mathrm{S}}$ patients studied and reached to $14.855 \pm 1.21$ $\mu \mathrm{IU} / \mathrm{ml}$ as compared with the control group $(6.2 \pm 1.0 \mu \mathrm{IU} / \mathrm{ml})$ which is statistically significantly ( $\mathrm{p}<0.05$ ), there was no significant difference between the two subgroups of PCOS (Fig 1).

\section{2- Follicle stimulating hormone} (FSH):

Serum FSA level was decreased in $63.87 \%$ ) of $\mathrm{PCO}_{\mathrm{S}}$ patients and reached to $(6.12 \pm 0.88 \mu \mathrm{IU} / \mathrm{ml})$ as compared with the control group $(8.30 \pm 0.8 \mu \mathrm{IU}$ $/ \mathrm{ml}$ ) and the $\mathrm{P}$ values was statistically significant.

\section{3- LH/FSH ratio}

LH/FSH ratio was markedly elevated in $(61.08 \%)$ of PCOs patients and reached to $(2.28 \mu \mathrm{IU})$ as compared with that found in the control group, which was statistically significant. The highest levels of LH/FSH values were found in PCOs with amenorrhea (3.88) No significant differences were found in aligomenorrhea group (Fig 1).

\section{4- Testosterone (T)}

Serum testosterone in patients with $\mathrm{PCO}_{\mathrm{S}}$ was markedly elevated in $(58.8 \%)$ and reached to $(3.87 \pm 1 . \mu \mathrm{IU}$ $/ \mathrm{ml})$ which was significantly higher than that found in control $(2.17 \pm 0.61$ $\mu \mathrm{IU} / \mathrm{ml}$ ). Highest $\mathrm{T}$ levels were found into two groups (Fig 1). 


\section{Discussion:}

Hormonal status profile in PCOs:-

The explanation of normal $\mathrm{LH}$ in PCOs might be based on typical and a typical PCOs in which LH level might be normal or might be due to increase pulse frequency or episodic secretion of LH as reported previously[14]. In spite of having normal base line LH levels[13].

Serum FSH levels in patients with PCOs were lower than that found in control group which were compatible with other studies but incompatible with reports of finding high FSH levels in case of raised LH levels in PCOs in England[13]

The explanation of higher LH/ FSH ratio might be due either to primary central disorders involving GnRH secretion or secondary pituitary sensitization to GnRH by an abnormal feed back signals from ovaries as suggested by other studies. Estrogens were able to increase LH response to GnRH compared with FSH, mainly if unopposed by progesterone that might lead to absence of negative feed- back mechanism on LH puls frequency in response to different $\mathrm{GnRH}$ pulse patter.

This could explain the highest LH/ FSH ratio in amenorrhiea group. Still there were controversies about the role of inhibin in preferential inhibition of FSH and not LH rendering elevated LH/ FSH ratio in PCOs in general as mentioned by many studies $[15,16]$.

Serum Testosterone levels of patients with PCOs whether had hirsutism or not were significantly higher than normal control. Highest levels of testosterone were found in patients with amenorrhea and oligomenorrhea in PCOs, which agreed with some studies [17,18]. Excess androgen secretion in PCOs is not always ovarian in origin, might be adrenal excess is the intial event that could transform into polycystic appearance. Nevertheless other suggest that increased androgen levels are a result and not cause of this endocrine disorders [19].

Table (2): Concentration of serum LH, FSH, and FSH:LH ratio \& testosterone hormones in PCOs and control groups

\begin{tabular}{|c|c|c|c|c|}
\hline & \multicolumn{4}{|c|}{ Hormonal assay $(\mathrm{m} . \pm \mathrm{SE})$} \\
\hline & $\begin{array}{c}\mathbf{L H} \\
(\mu \mathrm{IU} / \mathrm{ml})\end{array}$ & $\begin{array}{c}\text { FSH } \\
(\mu \mathrm{IU} / \mathrm{ml})\end{array}$ & $\begin{array}{c}\text { Testosterone } \\
(\mu \mathrm{IU} / \mathrm{ml})\end{array}$ & $\begin{array}{l}\text { LH:FSH } \\
\text { Ratio \% }\end{array}$ \\
\hline PCOs & $\begin{array}{c}\mathrm{A} \\
14.00 \pm 1.21\end{array}$ & $\begin{array}{c}\text { A } \\
6.12 \pm 0.88\end{array}$ & $\begin{array}{c}\mathrm{A} \\
3.87 \pm 1.48\end{array}$ & 2.28 \\
\hline Control & $\begin{array}{c}\text { B } \\
6.20 \pm 1.01\end{array}$ & $\begin{array}{c}\text { B } \\
8.30 \pm 0.8\end{array}$ & $\begin{array}{c}\text { B } \\
2.17 \pm 0.61\end{array}$ & 0.74 \\
\hline
\end{tabular}

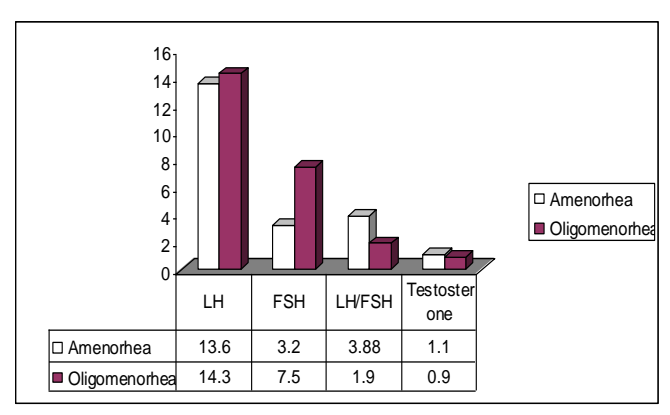

Fig. (1): Serum of hormones levels among the sub-groups of female with PCOs

\section{References:}

1. Carr. B.R and Blackwell R.E. 1993. Text book of productive Medicine. Second edition. Appleton and Lange. Cliaper 27, p.p. 233-243, 633-546.

2. Bardin CW. 1997. Current therapy in Endocrinology and Metabolism 6" ed. Mosby, p.p. 228-63, 359363.

3. Sarraf $M$ and Ghazzawi $I$. 1999.Poor ovarian responders-. a difficult problem to tackle, Middle East Ferti, Soc. J. 4(21 ):102-113.

4. Keri Marshall ND Candidate. 2001. Poly cystic ovary syndrome: clinical considerations. Alt. Med. Rev. 6(3): 272-292.

5. Melek Eda Ertorer, MD: inan Anafroglu, MD; Emre Bozkirli, 
MD; Okan Bakiner. 2007. A New perspective in Diagnosing Poly Cystic Ovary Syndrome, J of the National Med. Asso., 99(2):149152.

6. Jones H.W., and Jones G.S. 1980. "Gynecology" Williams and Wilkins/ Baltimore/ London/ $3^{\text {rd }}$ ed. P.p 350-410.

7. Lavery S and Trew G. 1998. Assisted conception: ethics and advances. Update - 4th February. p. 212-222.

8. Howard A. Zacur MD. 2001." polycystic Ovary Syndrome Hyperandrogenism and Insulin Resistance" Obstetrics and Gynecology Clinics .28(1): 21-33.

9. Jacobs H.S. and Conway G.S. 1999. Leptin, Poly Cystic Ovaries and Poly Cystic Ovary Syndrome, Human Reproduction Update, 15 (2): 166-171.

10. Sawaek Weerakiet MD 2004. Poly Cystic Ovary Syndrome and the metabolic Syndrome, J. Med. Association, 87(3): 189-193.

11. ESHRE Human reproduction. 2000.Vol. 15. Abstract Book i. June. Oxford University Press.

12. Robinson S, Henderson A.D, Gelding S.V and kiddy D.1996. Dyslipdaemia is associated with insulin resistance in women with Poly Cystic Ovaries. Clin Endocrinol Oxf: 44: 277-284 [Medline].

13. Franks S.T. 1989. "Poly Cystic Ovary Syndrome": a changing prespective Clin. Endocrinol. 31: 87-120.

14. Waldstreicher J., Santoro N.F., Hall J.E., Filicori and Crowely J,R. W.F 1988. "Hyper function of the hypothalamic axis in women with polycystic ovarian disease. J. Clin Endocrinol Metab. 66: 165-172.

15. Tanabe K., gaglano P., Channing C.P. and Nakamuray. F, 1983. "Levels of inhibit activity and steroids in human follicular fluid from normal women and women with polycystic ovarian disease" J. Clin. Endocrinal Metab. 57: 24-31.

16. Bukler H.M., Maclachan R.I. Maclachan V.B., Healy D.L and Burger H.G. 1988. "Serum inhibin level in polycystic ovary syndrome. Basal level and response to $\mathrm{LH}$ hormone" J. Clin. Endocrinol. 66:789-886.

17. Edan J.A., Place J., Carter G.D., Jones J., and Pawson MK. E 1989 " The dignosis of poly Cystic Ovaries in subfertile women" Br. J. obstel. Gynecol. 96: 809-815.

18. Edan J.A., Carter G.D., Place J., Jones J., and Pawson M. 1987. "Relationship between free androgen index and polycystic Ovaries in oligomenorrhea without obesity or hirsuties" J. Endocrinaol. 11: 29 (suppl).

19. Dunaif A. 1986. Do androgen directly regulate gonadotropin secretion in the poly cystic ovary syndrome?" J. Clin Endocrinol. Metab. 63: 215-221. 
قياس تركيز بعض الهرمونات في امصال مريضات متلازمة تكيسات المبيض بشرى فارس حسن*

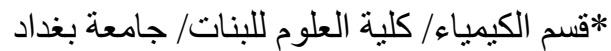

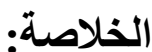

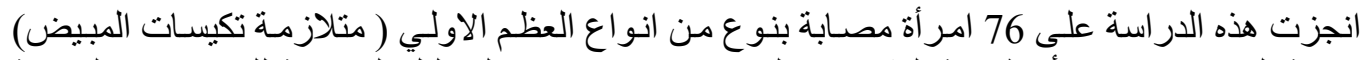

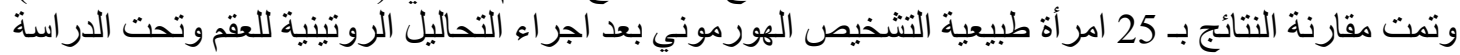
في مدة واحدة من الدورة الثهرية. قسمت النساء المصابات بـالمرض الى مجمو عتين اعتمـادا على نوع الاضطر ابات في الدورة الثشهرية وكالاتي: - n 254-1 كريضة ذات طمث قليل او متباعد.

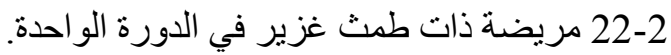

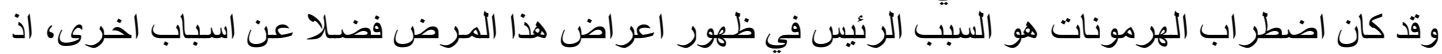

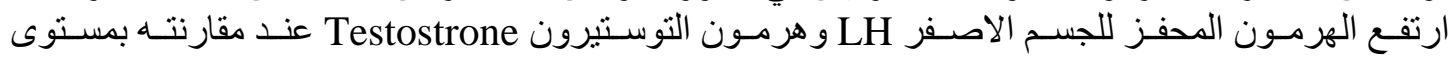

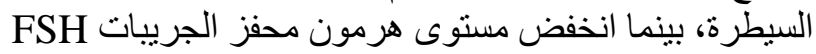

